\title{
SCHUR-CONVEXITY OF THE WEIGHTED ČEBIŠEV FUNCTIONAL
}

\section{VERA ČULJAK}

Abstract. In this paper the weighted Čebišev functional $T(p ; f, g ; a, b)$ is regarded as a function of two variables

$T(p ; f, g ; x, y)=\frac{\int_{x}^{y} p(t) f(t) g(t) d t}{\int_{x}^{y} p(t) d t}-\left(\frac{\int_{x}^{y} p(t) f(t) d t}{\int_{x}^{y} p(t) d t}\right)\left(\frac{\int_{x}^{y} p(t) g(t) d t}{\int_{x}^{y} p(t) d t}\right),(x, y) \in[a, b] \times[a, b]$

where $f, g$ and $p>0$ are Lebesgue integrable functions. The property of Schur-covexity (Schur-concavity) of this function is proved.

Mathematics subject classification (2010): Primary 26D15, Secondary 26D99.

Keywords and phrases: Convex functions, Schur-convex function, Čebišev functional, integral means.

\section{REFERENCES}

[1] V. ČUlJaK And J. PeČarić, Schur-convexity of Čebišev functional, Mathematical Inequalities \& Applications, accepted for publication.

[2] N. Elezović And J. PeČARIĆ, A Note on Schur-convrx functions, Rocky Mountain J. of Mathematics 30, 3 (2000), 853-856.

[3] A.W.MARShall AND I. OlKIn, Inequalities: Theory of Majorization and Its Applications, Academic Press Inc, New York, 1979.

[4] J. E. PeČArić, F. Proschan, And Y. L.Tong, Convex functions, partial orderings, and statistical applications, Academic Press Inc, 1992.

[5] F. QI, J. SÀndor, S.S. DRAGOMIR AND A. Sofo, Note on the Schur-convexity of the extended mean values, Taiwanese J. Math., 9 (2005), 411-420. 